\title{
Phytoextraction of rare earth elements in herbaceous plant species growing close to roads
}

\author{
Patrycja Mikolajczak $^{1}$ - Klaudia Borowiak ${ }^{1}$ - Przemyslaw Niedzielski ${ }^{2}$
}

Received: 8 November 2016/Accepted: 27 March 2017 / Published online: 14 April 2017

(C) The Author(s) 2017. This article is an open access publication

\begin{abstract}
The aim of study was to determine the phytoextraction of rare earth elements (REEs) to roots, stems and leaves of five herbaceous plant species (Achillea millefolium L., Artemisia vulgaris L., Papaver rhoeas L., Taraxacum officinale AND Tripleurospermum inodorum), growing in four areas located in close proximity to a road with varied traffic intensity. Additionally, the relationship between road traffic intensity, REE concentration in soil and the content of these elements in plant organs was estimated. A. vulgaris and P. rhoeas were able to effectively transport REEs in their leaves, independently of area collection. The highest content of REEs was observed in P. rhoeas leaves and T. inodorum roots. Generally, HREEs were accumulated in P. rhoeas roots and leaves and also in the stems of $T$. inodorum and T. officinale, whereas LREEs were accumulated in T. inodorum roots and T. officinale stems. It is worth underlining that there was a clear relationship between road traffic intensity and REE, HREE and LREE concentration in soil. No positive correlation was found between the concentration of these elements in soil and their content in plants, with the exception of $T$. officinale. An effective transport of REEs from the root system to leaves was observed, what
\end{abstract}

Responsible editor: Elena Maestri

Electronic supplementary material The online version of this article (doi:10.1007/s11356-017-8944-2) contains supplementary material, which is available to authorized users.

Patrycja Mikołajczak

patrycja.mikolajczak@up.poznan.pl

1 Department of Ecology and Environmental Protection, Poznan University of Life Sciences, Piątkowska 94C, 60-649 Poznań, Poland

2 Faculty of Chemistry, Adam Mickiewicz University in Poznań, Umultowska 89B, 61-614 Poznań, Poland points to the possible ability of some of the tested plant species to remove REEs from soils near roads.

Keywords Rare earth elements · Phytoextraction . Herbaceous plants $\cdot$ Traffic pollution

\section{Introduction}

There are only a relatively low number of investigations concerning rare earth elements (REEs) in comparison to other groups of elements characterized in various environmental components (Tyler 2004; Bentlin and Pozebon 2010; Zhang et al. 2013; Mleczek et al. 2016a,b;). This is mainly connected with analytical problems, both the lack of proper equipment and lack of reference materials (Cao et al. 2000). REEs, contrary to commonly held opinion, are not a rarely occurring group of elements in the environment. This has been proved e.g. by investigations on neodymium $(\mathrm{Nd})$ or scandium $(\mathrm{Sc})$. The content of REEs in the environment is increasing due to the development of modern technologies and a consequent elevated need for selected elements concerning the type of final product (EPA 600/R-12/572 2012). REEs are important in many branches of the economy, such as agriculture, the petroleum industry, applications in television and information technology. The use of rare elements in many products improves the features of other elements by increasing their resistance, conductivity, strength and decreasing the weight and size of the final product (Klinger 2015).

According to Klinger (2015), there are 17 rare earth elements which represent approx. $17 \%$ of all elements occurring in the natural environment. On the other hand, Gambogi (2011) divided REEs into two groups: heavy rare earth elements (HREEs) and light rare earth elements (LREEs). The following are considered to be LREEs: scandium $\left({ }^{21} \mathrm{Sc}\right)$, 
yttrium $\left({ }^{39} \mathrm{Y}\right)$, terbium $\left({ }^{65} \mathrm{~Tb}\right)$, dysprosium $\left({ }^{66} \mathrm{Dy}\right)$, holmium $\left({ }^{67} \mathrm{Ho}\right)$, erbium $\left({ }^{68} \mathrm{Er}\right)$, thulium $\left({ }^{69} \mathrm{Tm}\right)$, ytterbium $\left({ }^{70} \mathrm{Yb}\right)$ and lutetium $\left({ }^{71} \mathrm{Lu}\right)$, while HREEs are: lanthanum $\left({ }^{57} \mathrm{La}\right)$, cerium $\left({ }^{58} \mathrm{Ce}\right)$, praseodymium $\left({ }^{59} \mathrm{Pr}\right)$, neodymium $\left({ }^{60} \mathrm{Nd}\right)$, promethium $\left({ }^{61} \mathrm{Pm}\right)$, samarium $\left({ }^{62} \mathrm{Sm}\right)$, europium $\left({ }^{63} \mathrm{Eu}\right)$ and gadolinium $\left({ }^{64} \mathrm{Gd}\right)$. Other researchers have described REEs as a group of 14 elements belonging to lanthanides beginning from ${ }^{57} \mathrm{La}$ to ${ }^{71} \mathrm{Lu}$ (Laveuf and Cornu 2009).

The concentration of REEs has been analysed in soil (Laveuf and Cornu 2009), water cultures (Ding et al. 2005), and in plants (Nakamaru et al. 2006; Bluemel et al. 2013; Zhang et al. 2015). In the case of plants, REEs were characterized with respect to the possibility of selecting ligands for complexation of these elements, and modulation of their phytoextraction efficiency, both from soil and water cultures (Byrne et al. 1996; Ding et al. 2005). REEs have been analysed in numerous types of plants: lichens, mosses or vascular plants (Chiarenzelli et al. 2001), such as maize plants (Saatz et al. 2015) or the functional group of grasses (Wiche and Heilmeier 2016). The general characteristics of REE content in numerous components of the environment is presented in Supplemementary data (Table S1).

The use of automotive catalytic converters for almost 50 years has increased the amount of platinum group elements (PGE). On the other hand, some authors have focused on numerous other elements, such as REEs (Djingova et al. 2003). The increase in their concentration in soil can be associated with the rapid development of new technologies (Carrero et al. 2013). Owing to the transport of these elements and their implementation in the production of selected parts of cars, their content in soil and accumulation in plants that grow close to roads has increased (Figueiredo et al. 2009).

For this reason, the aim of present study was to evaluate: $i)$ the efficiency of REEs phytoextraction to roots, stems and leaves of Achillea millefolium L., Artemisia vulgaris L., Papaver rhoeas L., Taraxacum officinale G.H. Wigg. AND Tripleurospermum inodorum L. samples collected from four different locations, ii) the similarities and differences between plant species and iii) the relationship between road traffic intensity, REEs concentration in soil and the content of these elements in organs of the tested plants collected from all experimental areas.

\section{Materials and methods}

\section{Experiment design}

Plant samples were collected from near the road and in the vicinity of petrol stations located in the villages of
Sława Wielkopolska (Areas A1 and A2) and Czerwonak (Areas A3 and A4). In this study, five herbaceous plant species, growing at four areas located along roads 196 and $31,5 \mathrm{~km}$ north of the city of Poznan (Western Poland), were collected. Particular experimental areas were diverse as regards traffic intensity (Table 1) and their location at petrol stations, or within approximately $400 \mathrm{~m}$ of them (Fig. 1).

The data presented in Table 1 were obtained between 8th and 11th August 2015 and 2016, respectively, when the number of passing motor vehicles was counted at each experimental area between 8 a.m. and 8 p.m.

\section{Experimental materials}

Soil samples were collected from the topsoil (to maximal depth of $15 \mathrm{~cm}$ ) to the amount of $0.5 \mathrm{~kg}$, which was an average from 15 samples of soil collected using a sand auger (AMS, Inc.) with a diameter of $3.8 \mathrm{~cm}\left(1.5^{\prime \prime}\right)$. The characteristics of the experimental areas are presented in Table 2.

Experimental material consisted of 5 popular herbaceous plant (weed) species: Achillea millefolium L., Artemisia vulgaris L., Papaver rhoeas L., Tripleurospermum inodorum (L.) Sch. Bip. AND Taraxacum officinale F. H. WIGG., selected on the grounds of their common presence in the environment, growth in close proximity to the road at the experimental areas, resistance to unfavourable weather conditions and rapid growth. With the exception of P. rhoeas L., which BeLONGS TO the Papaveraceae family, the other four plant species belong to the Asteraceae family. Selection of the just plant species was an effect of their presence of the each year and possibility to collect the plants with the similar biomass. The mean biomass $[\mathrm{g}]$ of collected herbaceous plant species were as follow: $2.535 \pm 0.475$ (A. millefolium), $26.036 \pm 4.063$ (A. vulgaris), $17.065 \pm 2.479$ (T. inodorum), $11.005 \pm 2.560$ (P. rhoeas) and $4.385 \pm 1.189$ ( $T$. officinale) with the percentage share of biomass of roots in whole plants biomass: $23.3 ; 14.2 ; 27.2 ; 39.3$ and $33.2 \%$, respectively.

\section{Sample collection and preparation}

All weed species were collected from four experimental areas $(n=4)$ as 4 individual plants from each area on 12th August 2015 in drought conditions after a period of 13 days without rainfall, and 13th August 2016 after some rainy days (Supplementary data, Table S2). Both soil and plants were collected within 1-2 $\mathrm{m}$ distance of the road. Each plant was divided into three organs (roots, stems and leaves), dried using an electric oven TC 100 (SalvisLAB, Switzerland) at $105 \pm 3{ }^{\circ} \mathrm{C}$ for $96 \mathrm{~h}$ and ground for $3 \mathrm{~min}$ in a Cutting Mill SM 200 (Retsch, Germany). Before 
Table 1 Characteristics of motor vehicles intensity at experimental areas

\begin{tabular}{|c|c|c|c|c|c|c|c|c|}
\hline \multirow{2}{*}{$\begin{array}{l}\text { Mean amount of motor } \\
\text { vehicles }\end{array}$} & \multicolumn{4}{|l|}{2015} & \multicolumn{4}{|l|}{2016} \\
\hline & $\begin{array}{l}\text { Area } 1 \\
\text { PS* } \\
9655\end{array}$ & $\begin{array}{l}\text { Area } \\
2 \\
9472\end{array}$ & $\begin{array}{l}\text { Area } 3 \\
\text { PS* } \\
17,438\end{array}$ & $\begin{array}{l}\text { Area } 4 \\
17,097\end{array}$ & $\begin{array}{l}\text { Area } 1 \\
\text { PS* } \\
9716\end{array}$ & $\begin{array}{l}\text { Area } \\
2 \\
9503\end{array}$ & $\begin{array}{l}\text { Area } 3 \\
\text { PS* }^{*} \\
17,699\end{array}$ & $\begin{array}{l}\text { Area } 4 \\
17,204\end{array}$ \\
\hline Motocycles & 106 & 99 & 206 & 204 & 75 & 72 & 227 & 197 \\
\hline Passengercars & 7948 & 7860 & 14,344 & 14,135 & 8132 & 7943 & 14,792 & 14,212 \\
\hline Delivery vans & 790 & 735 & 1423 & 1343 & 804 & 766 & 1469 & 1423 \\
\hline Lorries & 695 & 677 & 1256 & 1211 & 602 & 626 & 1244 & 1243 \\
\hline Buses & 87 & 72 & 157 & 157 & 82 & 66 & 127 & 90 \\
\hline Tractors & 29 & 29 & 52 & 47 & 21 & 30 & 67 & 39 \\
\hline
\end{tabular}

*PS - nearby petrol station drying roots and leaves were washed in deionized water to remove remaining soil particles from the root systems and any surface dust absorbed by leaves that could contain REEs ions. Three samples prepared for each plant organ were digested using a microwave mineralization system CEM Mars 5 Xpress (CEM, USA). $0.3000 \pm 0.0001 \mathrm{~g}$ of sample was placed in $55 \mathrm{~mL}$ vessels with $7 \mathrm{~mL}$ of concentrated $(65 \%) \mathrm{HNO}_{3}$ and $1 \mathrm{~mL}$ of $\mathrm{H}_{2} \mathrm{O}_{2}$ (both of analytical purity, Merck, Germany). The digestion programme consisted of the following stages: first stage $-10 \mathrm{~min}$ at power $600 \mathrm{~W}$, temperature $80{ }^{\circ} \mathrm{C}$; second stage $-10 \mathrm{~min}$ at power $1200 \mathrm{~W}$, temperature $120{ }^{\circ} \mathrm{C}$; third stage $-12 \mathrm{~min}$ at power $1600 \mathrm{~W}$, temperature $200{ }^{\circ} \mathrm{C}$. After digestion the solutions were filtrated through Qualitative Filter Papers (Grade 595: 4-7 $\mu \mathrm{m}$ Whatman, GB) and filled (to protect the analytical instrument) with deionized water Milli-Q Advantage A10 Water Purification Systems (Merck Millipore, Germany) to a final volume of $50 \mathrm{~mL}$. Soil samples were digested in the same way as plant material but after mercerization for $24 \mathrm{~h}$.

\section{Analytical methods}

REEs determination was carried out using inductively coupled plasma optical emission spectrometry (ICP-OES) with an Agilent 5100 (Agilent, USA) spectrometer. The dual (synchronous) axial and radial plasma view was used. The

Fig. 1 Map of the sampled areas

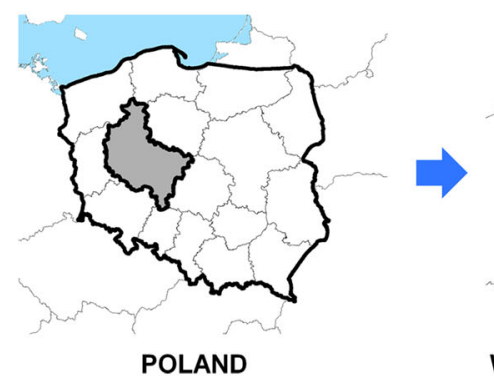

POLAND

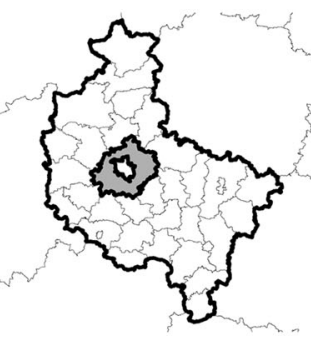

WIELKOPOLSKA REGION

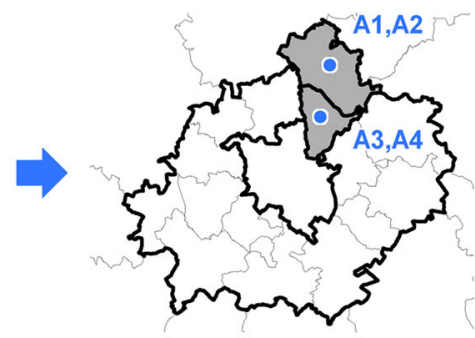

POZNAŃSKI COUNTY

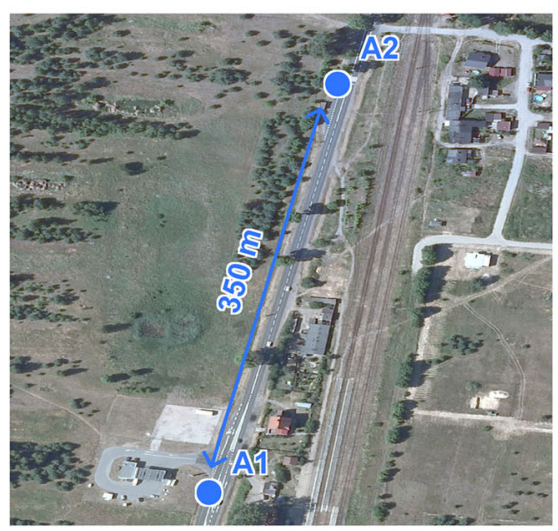

SŁAWA WIELKOPOLSKA VILLAGE

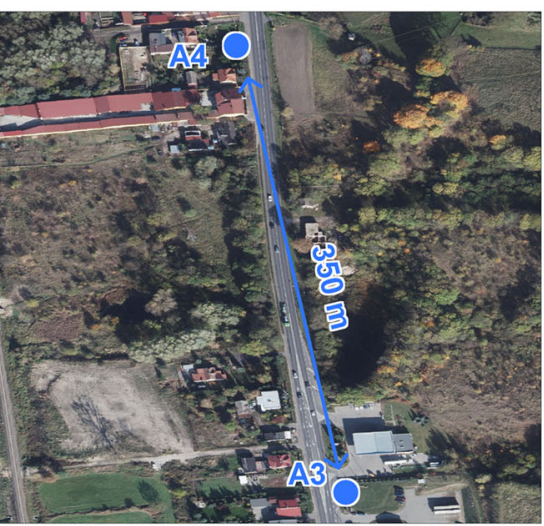

CZERWONAK VILLAGE 
Table 2 Characteristics of experimental areas of plant samples collection with data of elements concentration $\left[\mathrm{mg} \mathrm{kg}^{-1} \mathrm{DW}\right]$ in soil

\begin{tabular}{|c|c|c|c|c|c|}
\hline \multirow[t]{2}{*}{ Data } & \multirow[t]{2}{*}{ Unit } & \multicolumn{2}{|l|}{ Sława Wielkopolska village } & \multicolumn{2}{|l|}{ Czerwonak village } \\
\hline & & $\begin{array}{l}\text { petrol station } \\
\text { Area } 1 \text { (A1) }\end{array}$ & $\begin{array}{l}\text { road } \\
\text { Area } 2 \text { (A2) }\end{array}$ & $\begin{array}{l}\text { petrol station } \\
\text { Area } 3(\mathrm{~A} 3)\end{array}$ & $\begin{array}{l}\text { road } \\
\text { Area } 4(\mathrm{~A} 4)\end{array}$ \\
\hline GPS* position & & $52^{\circ} 38^{\prime} 3.86^{\prime \prime} \mathrm{N} 17^{\circ} 8^{\prime} 35.25^{\prime \prime} \mathrm{E}$ & $52^{\circ} 38^{\prime} 15.50^{\prime \prime} \mathrm{N} 17^{\circ} 8^{\prime} 39.05^{\prime \prime} \mathrm{E}$ & $52^{\circ} 27^{\prime} 25.52^{\prime \prime} \mathrm{N} 16^{\circ} 59^{\prime} 3.27^{\prime \prime} \mathrm{E}$ & $52^{\circ} 27^{\prime} 37.94^{\prime \prime} \mathrm{N} 16^{\circ} 59^{\prime} 1.48^{\prime \prime} \mathrm{E}$ \\
\hline Elevation* & $\mathrm{m}$ & 78 & 79 & 62 & 64 \\
\hline Element & & \multicolumn{2}{|l|}{ Chemical characteristics of soil } & & \\
\hline$P$ & $\mathrm{mg} \mathrm{kg}^{-1}$ & $505^{\mathrm{a}} \pm 61$ & $416^{\mathrm{a}} \pm 11$ & $468^{\mathrm{a}} \pm 39$ & $440^{\mathrm{a}} \pm 20$ \\
\hline S & $\%$ & $0.021^{\mathrm{a}} \pm 0.002$ & $0.023^{\mathrm{a}} \pm 0.002$ & $0.019^{\mathrm{a}} \pm 0.002$ & $0.020^{\mathrm{a}} \pm 0.001$ \\
\hline $\mathrm{Ca}$ & $\mathrm{mg} \mathrm{kg}^{-1}$ & $1240^{\mathrm{b}} \pm 30$ & $1210^{\mathrm{b}} \pm 90$ & $9540^{\mathrm{a}} \pm 690$ & $9520^{\mathrm{a}} \pm 250$ \\
\hline $\mathrm{K}$ & $\mathrm{mg} \mathrm{kg}^{-1}$ & $400^{b} \pm 23$ & $456^{\mathrm{b}} \pm 34$ & $983^{\mathrm{a}} \pm 30$ & $866^{\mathrm{a}} \pm 63$ \\
\hline $\mathrm{Mg}$ & $\mathrm{mg} \mathrm{kg}^{-1}$ & $554^{\mathrm{b}} \pm 18$ & $606^{\mathrm{b}} \pm 113$ & $1210^{\mathrm{a}} \pm 90$ & $1160^{\mathrm{a}} \pm 60$ \\
\hline \multirow[t]{2}{*}{$\mathrm{Na}$} & $\mathrm{mg} \mathrm{kg}^{-1}$ & $94^{\mathrm{b}} \pm 10$ & $118^{\mathrm{ab}} \pm 17$ & $142^{\mathrm{ab}} \pm 18$ & $150^{\mathrm{a}} \pm 21$ \\
\hline & & \multicolumn{2}{|l|}{ LREEs } & & \\
\hline $\mathrm{Ce}$ & $\mathrm{mg} \mathrm{kg}^{-1}$ & $19.3^{\mathrm{b}} \pm 1.6$ & $19.5^{\mathrm{b}} \pm 1.8$ & $25.9^{\mathrm{a}} \pm 0.8$ & $24.2^{\mathrm{a}} \pm 1.3$ \\
\hline $\mathrm{Eu}$ & & $0.19^{\mathrm{ab}} \pm 0.02$ & $0.15^{\mathrm{b}} \pm 0.01$ & $0.23^{\mathrm{a}} \pm 0.02$ & $0.22^{\mathrm{a}} \pm 0.03$ \\
\hline $\mathrm{Gd}$ & & $0.24^{\mathrm{b}} \pm 0.01$ & $0.21^{\mathrm{b}} \pm 0.02$ & $1.91^{\mathrm{a}} \pm 0.06$ & $1.86^{\mathrm{a}} \pm 0.15$ \\
\hline $\mathrm{La}$ & & $1.02^{\mathrm{b}} \pm 0.03$ & $0.95^{\mathrm{b}} \pm 0.03$ & $6.75^{\mathrm{a}} \pm 0.23$ & $6.27^{\mathrm{a}} \pm 0.46$ \\
\hline $\mathrm{Nd}$ & & $7.31^{\mathrm{b}} \pm 0.07$ & $7.75^{\mathrm{b}} \pm 0.68$ & $14.1^{\mathrm{a}} \pm 0.8$ & $13.4^{\mathrm{a}} \pm 0.4$ \\
\hline $\operatorname{Pr}$ & & $1.01^{\mathrm{b}} \pm 0.05$ & $1.06^{\mathrm{b}} \pm 0.13$ & $1.80^{\mathrm{a}} \pm 0.16$ & $1.55^{\mathrm{a}} \pm 0.11$ \\
\hline \multirow[t]{2}{*}{$\mathrm{Sm}$} & & $0.04^{\mathrm{a}} \pm 0.02$ & $0.04^{\mathrm{a}} \pm 0.01$ & $0.03^{\mathrm{a}} \pm 0.02$ & $0.05^{\mathrm{a}} \pm 0.01$ \\
\hline & & \multicolumn{2}{|l|}{ HREEs } & & \\
\hline Dy & $\mathrm{mg} \mathrm{kg}^{-1}$ & $0.90^{\mathrm{a}} \pm 0.02$ & $0.83^{\mathrm{a}} \pm 0.06$ & $0.64^{\mathrm{b}} \pm 0.04$ & $0.65^{\mathrm{b}} \pm 0.02$ \\
\hline Er & & $28.5^{\mathrm{b}} \pm 2.4$ & $30.8^{b} \pm 1.3$ & $48.1^{\mathrm{a}} \pm 3.0$ & $45.9^{\mathrm{a}} \pm 1.1$ \\
\hline Но & & $\mathrm{bDL}^{* *}$ & $\mathrm{bDL}$ & $0.04^{\mathrm{a}} \pm 0.02$ & $0.04^{\mathrm{a}} \pm 0.01$ \\
\hline $\mathrm{Lu}$ & & $0.11^{\mathrm{c}} \pm 0.02$ & $0.12^{\mathrm{c}} \pm 0.01$ & $0.19^{\mathrm{a}} \pm 0.03$ & $0.18^{\mathrm{b}} \pm 0.01$ \\
\hline $\mathrm{Sc}$ & & $0.41^{\mathrm{b}} \pm 0.02$ & $0.40^{\mathrm{b}} \pm 0.02$ & $0.94^{\mathrm{a}} \pm 0.04$ & $0.88^{\mathrm{a}} \pm 0.03$ \\
\hline $\mathrm{Tb}$ & & $0.11^{\mathrm{b}} \pm 0.02$ & $0.13^{\mathrm{b}} \pm 0.02$ & $0.26^{\mathrm{a}} \pm 0.03$ & $0.27^{\mathrm{a}} \pm 0.02$ \\
\hline $\mathrm{Tm}$ & & $0.41^{\mathrm{c}} \pm 0.03$ & $0.45^{\mathrm{c}} \pm 0.02$ & $1.20^{\mathrm{a}} \pm 0.03$ & $1.05^{\mathrm{b}} \pm 0.03$ \\
\hline $\mathrm{Yb}$ & & $0.26^{\mathrm{b}} \pm 0.02$ & $0.28^{\mathrm{b}} \pm 0.02$ & $0.38^{\mathrm{a}} \pm 0.02$ & $0.36^{\mathrm{a}} \pm 0.03$ \\
\hline $\mathrm{Y}$ & & $1.79^{\mathrm{b}} \pm 0.15$ & $1.93^{\mathrm{b}} \pm 0.05$ & $2.68^{\mathrm{a}} \pm 0.04$ & $2.53^{\mathrm{a}} \pm 0.08$ \\
\hline $\mathrm{pH}$ & & $6.29^{\mathrm{ab}} \pm 0.02$ & $6.35^{\mathrm{a}} \pm 0.01$ & $6.21^{\mathrm{b}} \pm 0.03$ & $6.25^{\mathrm{b}} \pm 0.04$ \\
\hline $\mathrm{EC}$ & $\mathrm{mS} \mathrm{cm}^{-1}$ & $498^{\mathrm{bc}} \pm 24$ & $464^{\mathrm{c}} \pm 14$ & $623^{\mathrm{a}} \pm 11$ & $555^{\mathrm{b}} \pm 23$ \\
\hline Redox & $\mathrm{eV}$ & $218^{a} \pm 14$ & $216^{\mathrm{a}} \pm 13$ & $258^{\mathrm{a}} \pm 18$ & $238^{a} \pm 22$ \\
\hline
\end{tabular}

*determined using the Global Positioning System (GPS) by GPS Navigator Oregon $550 \mathrm{t}$ (Garmin, USA)

**bDL-below Detection Limit

instrumental parameters common for determination of all elements were: RF power $1.2 \mathrm{~kW}$, plasma gas (argon) flow $12 \mathrm{~L}$ $\min ^{-1}$, nebuliser gas (argon) flow $0.7 \mathrm{~L} \mathrm{~min}^{-1}$, radial view height $8 \mathrm{~mm}$. For REE determination the following wavelengths were used: Ce $446.021 \mathrm{~nm}$; Dy $400.045 \mathrm{~nm}$; Er $349.910 \mathrm{~nm}$; Eu $420.504 \mathrm{~nm}$; Gd $342.246 \mathrm{~nm}$; Ho $348.484 \mathrm{~nm}$; La $333.749 \mathrm{~nm}$; Lu $307.760 \mathrm{~nm}$; Nd $406.108 \mathrm{~nm}$; Pr $417.939 \mathrm{~nm}$; Sc $361.383 \mathrm{~nm}$; Sm $442.434 \mathrm{~nm}$; Tb $350.914 \mathrm{~nm}$; Tm $336.261 \mathrm{~nm}$; Y $361.104 \mathrm{~nm}$; Yb $328.937 \mathrm{~nm}$.

Analysis of $\mathrm{pH}$, redox potential, electrolytic conduction, and dry matter to characterize soils from particular areas were performed according to Polish and European norms (PN-ISO 10390 1997, ISO 11271 2002, PN-ISO 1265+AC1 1997 and PN-ISO 11465 1999, respectively). For pH, redox potential and electrolytic conduction the multiparametric system 350 (WTW, Germany) has been used.

\section{Control of quality of results}

In traceability control the certified standard material CRM NCSDC (73349) - bush branches and leaves was applied (NACIS, China). The recovery values were: Ce 119\%; Dy 77\%; Eu 77\%; Gd 105\%; Ho 82\%; La 87\%; Lu 91\%; Nd 
110\%; Pr 83\%; Sm 118\%; Yb 79\% respectively. Because the Er and Sc concentration was not certified, an analysis of the certified standard material CRM 667 (sediment) was provided additionally (IRMM, Belgium). The obtained recoveries were: Er $105 \%$ and Sc 107\%. The recovery values in the range of $75-125 \%$ were recognized as satisfied.

\section{Statistical analysis}

The results were analysed with a factorial ANOVA with "plant species" and "plant organ" as fixed factors. Tukey's test was employed to analyse differences between measured parameters. A graphical presentation of Tukey's test results is provided in the present study. To determine the structure and relations between variables, principal component analysis (PCA) was used. In this analysis the orthogonal transformation of observed variables to a new set of non-correlated variables (components) is performed.

For the analyses of similarities and differences of REEs accumulation in certain plants within the experimental areas in regard to transport intensity and petrol station location cluster analysis was performed. Euclidean distance measures and Ward hierarchical clustering were used to determine the dendrogram with two or three groups. The certain Euclidean distance measure can designate a similarity structure in interactions between analysed parameters. The cluster analysis was carried out for LREE and HREE separately. The above data analyses were done with the statistical software STATISTICA 12.1 (StatSoft, USA).

To characterize the phytoextraction efficiency of LHREEs, HREEs and REEs, the bioconcentration factor (BCF) values were calculated according to eq. 1, as the ratio of the concentration of these elements in plant harvested organs to their concentration in soil (Ali et al. 2013).

$\mathrm{BCF}=\frac{\text { LREEs } / \mathrm{HREES} / \text { REEs concentration in the root }\left(\mathrm{mg} \mathrm{kg}^{-1} \mathrm{DW}\right)}{\text { LREEs } / \mathrm{HREEs} / \text { REEs concentration in soil }\left(\mathrm{mg} \mathrm{kg}^{-1} \mathrm{DW}\right)}$

Moreover, to show the efficiency of REEs transport from roots to stems, the Translocation Factor (TF) values were calculated according to Yu and Zhou (2009) and the following formula (eq. 2).

$$
\mathrm{TF}=\frac{\text { LREEs } / \text { HREEs } / \text { REEs content in stems }\left(\mathrm{mg} \mathrm{kg}^{-1} \mathrm{DW}\right)}{\text { LREEs } / \text { HREEs } / \text { REEs content in roots }\left(\mathrm{mg} \mathrm{kg}^{-1} \mathrm{DW}\right)}
$$

\section{Results}

The results obtained in this study were prepared as preliminary mean values calculated for two years of studies performed in the environment. With respect to the same relations between the tested phytoextraction ability of plant species for REEs in 2015 and 2016 and the difference in the level of these elements in plant organs analysed in particular years, the results presented below are characteristic of materials analysed in 2015 only, with the appropriate comments in the final part of this section.

\section{Total content of rare earth elements in plant organs}

The total amount of REEs is presented in Table 3 to illustrate differences in the effectiveness of their phytoextraction to roots, stems and leaves of the investigated herbaceous plant species. Significant differences in REEs contents are indicated between plant organs. The highest content was noted in leaves of $P$. rhoeas collected from Area 1 and Area 2 (85.3 \pm 8.6 and $50.6 \pm 6.0 \mathrm{mg} \mathrm{kg}^{-1} \mathrm{DW}$, respectively), roots of $\boldsymbol{T}$. inodorum collected from Area $3\left(71.7 \pm 5.1 \mathrm{mg} \mathrm{kg}^{-1} \mathrm{DW}\right)$ and leaves of A. millefolium, . inodorum and T. officinale $(38.2 \pm 1.1$, $44.5 \pm 6.4$ and $35.8 \pm 3.7 \mathrm{mg} \mathrm{kg}^{-1} \mathrm{DW}$, respectively) sampled from Area 4.

Moreover, the highest content of REEs was found in the leaves of A. vulgaris and P. rhoeas in comparison to their content in roots and stems independent of experimental area while the highest content of REEs was recorded in leaves and roots of A. millefolium and T. inodorum, depending on the place of collection (Table 3 ).

\section{Content of heavy rare earth elements}

Two-way analysis of variance revealed the highly significant $(\alpha \leq 0.001)$ effect of plant species and plant organs of almost all analysed HREEs, excluding the effect of plant organs and their interaction with species for Ho in Area 1 and $\mathrm{Tb}$ in Area 4 (Table S3 in Supplementary data). Total content of HREEs in plant species collected from the tested areas was significantly diverse (Tables S4-S7 in Supplementary data). In the case of Area 1, the highest content of HREEs was recorded in roots and leaves of $P$. rhoeas (29.4 and $9.40 \mathrm{mg} \mathrm{kg}^{-1} \mathrm{DW}$, respectively) and $T$. inodorum roots $\left(19.4 \mathrm{mg} \mathrm{kg}^{-1} \mathrm{DW}\right)$. The highest content of HREEs was observed in $P$. rhoeas leaves and T. inodorum stems (27.6 and $8.10 \mathrm{mg} \mathrm{kg}^{-1} \mathrm{DW}$, respectively) growing in Area 2 . For both experimental areas, $\mathrm{Tb}$ and Dy contents were similar to the limits of detection of these elements. Similar findings were recorded for Ho, with the exception of all A. vulgaris organs collected from Area 1, where the content of this element was about $0.04 \mathrm{mg} \mathrm{kg}^{-1}$ DW. For the remaining HREEs, the highest content of Er, $\mathrm{Tm}, \mathrm{Y}$ and $\mathrm{Sc}$ was noted in $T$. inodorum roots $(18.1, \mathbf{0 . 2 6}$, 
Table 3 Content of total rare earth elements [ $\left.\mathrm{mg} \mathrm{kg}^{-1} \mathrm{DW}\right]$ in organs of plant species growing at experimental areas

\begin{tabular}{llllll}
\hline Plant species & Plant organ & Area 1 & Area 2 & Area 3 & Area 4 \\
\hline A. millefolium & Root & $74.4^{\mathrm{b}} \pm 1.6$ & $8.89^{\mathrm{gh}} \pm 0.39$ & $27.5^{\mathrm{ef}} \pm 1.5$ & $31.3^{\mathrm{bc}} \pm 1.9$ \\
& Stem & $32.7^{\mathrm{efg}} \pm 2.1$ & $12.7^{\mathrm{fgh}} \pm 0.5$ & $29.0^{\mathrm{def}} \pm 1.7$ & $14.7^{\mathrm{efgh}} \pm 2.3$ \\
& Leaf & $44.9^{\mathrm{cd}} \pm 2.1$ & $36.4^{\mathrm{bc}} \pm 2.4$ & $24.4^{\mathrm{f}} \pm 2.2$ & $38.2^{\mathrm{ab}} \pm 1.1$ \\
A. vulgaris & Root & $15.9^{\mathrm{hi}} \pm 0.7$ & $10.4^{\mathrm{fgh}} \pm 0.6$ & $11.1^{\mathrm{g}} \pm 0.6$ & $8.60^{\mathrm{gh}} \pm 0.70$ \\
& Stem & $24.7^{\mathrm{gh}} \pm 1.0$ & $12.3^{\mathrm{fgh}} \pm 1.1$ & $11.8^{\mathrm{g}} \pm 3.8$ & $9.60^{\mathrm{fgh}} \pm 0.90$ \\
& Leaf & $37.1^{\mathrm{def}} \pm 1.1$ & $23.1^{\mathrm{de}} \pm 2.3$ & $35.7^{\mathrm{cde}} \pm 3.6$ & $22.9^{\mathrm{cde}} \pm 3.1$ \\
T. inodorum & Root & $74.4^{\mathrm{b}} \pm 1.6$ & $29.6^{\mathrm{cd}} \pm 0.5$ & $71.7^{\mathrm{a}} \pm 5.1$ & $22.3^{\mathrm{de}} \pm 1.4$ \\
& Stem & $32.7^{\mathrm{efg}} \pm 2.1$ & $22.0^{\mathrm{de}} \pm 1.0$ & $24.3^{\mathrm{f}} \pm 4.2$ & $18.2^{\mathrm{ef}} \pm 0.8$ \\
& Leaf & $44.9^{\mathrm{cd}} \pm 2.1$ & $38.1^{\mathrm{b}} \pm 3.5$ & $38.5^{\mathrm{bcd}} \pm 1.9$ & $44.5^{\mathrm{a}} \pm 6.4$ \\
& Root & $52.4^{\mathrm{c}} \pm 1.1$ & $17.6^{\mathrm{ef}} \pm 0.4$ & $46.7^{\mathrm{b}} \pm 1.2$ & $17.9^{\mathrm{ef}} \pm 1.5$ \\
& Stem & $25.3^{\mathrm{gh}} \pm 2.5$ & $33.2^{\mathrm{bc}} \pm 1.5$ & $19.0^{\mathrm{fg}} \pm 1.1$ & $7.20^{\mathrm{h}} \pm 1.50$ \\
& Leaf & $85.3^{\mathrm{a}} \pm 8.6$ & $50.6^{\mathrm{a}} \pm 6.0$ & $44.5^{\mathrm{bc}} \pm 3.7$ & $17.3^{\mathrm{efg}} \pm 1.0$ \\
& Root & $10.0^{\mathrm{i}} \pm 0.6$ & $5.40^{\mathrm{h}} \pm 0.20$ & $36.9^{\mathrm{bcde}} \pm 0.8$ & $16.5^{\mathrm{efg}} \pm 0.3$ \\
& Stem & $27.9^{\mathrm{fg}} \pm 1.2$ & $15.3^{\mathrm{efg}} \pm 0.9$ & $44.6^{\mathrm{bc}} \pm 1.5$ & $29.7^{\mathrm{bcd}} \pm 1.8$ \\
& Leaf & $39.1^{\mathrm{de}} \pm 3.0$ & $22.0^{\mathrm{de}} \pm 1.5$ & $44.0^{\mathrm{bc}} \pm 3.6$ & $35.8^{\mathrm{ab}} \pm 3.7$ \\
\hline
\end{tabular}

$n=4$, mean values $\pm \mathrm{SD}$; identical letters $(\mathrm{a}, \mathrm{b}, \mathrm{c} . .$.$) followed by values denote no significant (p=0.05)$ difference in columns according to Tukey's HSD test (ANOVA)
0.75 and $0.19 \mathrm{mg} \mathrm{kg}^{-1} \mathrm{DW}$, respectively) and $P$. rhoeas roots (28.7, $0.11,0.45$ and $0.11 \mathrm{mg} \mathrm{kg}^{-1} \mathbf{D W}$, respectively) growing in Area 1. In the case of plants collected from Area 2, the highest content of these elements were found in T. inodorum stems (7.50, 0.11, 0.27 and $0.11 \mathrm{mg} \mathrm{kg}^{-1} \mathrm{DW}$, respectively) and $P$. rhoeas leaves $\left(26.5,0.22,0.65\right.$ and $0.18 \mathrm{mg} \mathrm{kg}^{-1} \mathbf{D W}$, respectively).

The content of HREEs in plants collected from Areas 3 and 4 was more diverse than in plants from the two previous areas. In the case of Area 3, the highest content of total HREEs was noted in $P$. rhoeas and $\boldsymbol{T}$. inodorum roots $(17.7$ and $9.96 \mathrm{mg}$ $\mathrm{kg}^{-1} \mathrm{DW}$, respectively), while from Area 4 in $P$. rhoeas and A. millefolium roots $\left(6.78\right.$ and $5.65 \mathrm{mg} \mathrm{kg}^{-1} \mathrm{DW}$, respectively). Content of $\mathrm{Dy}$ and $\mathrm{Tb}$ was similar to their limits of detection with the exception of all $P$. rhoeas organs (Dy) growing in Area 4 and also all organs of $P$. rhoeas and $T$. officinale from Area 3 and $P$. rhoeas from Area 4, where their content was significantly higher in comparison to other values. In the case of the remaining elements, the highest amount of Er, Tm, Y and Sc was observed in P. rhoeas roots from Area 3 (15.6, $0.26,1.27$ and $0.22 \mathrm{mg} \mathrm{kg}^{-1} \mathrm{DW}$, respectively) and Area 4 (5.99, $0.10,0.49$ and $0.09 \mathrm{mg} \mathrm{kg}^{-1} \mathrm{DW}$, respectively). It is also worth underlining, that $A$. millefolium collected from Area 4 was characterized by the highest content of $\mathrm{Er}$ in its roots and leaves, $\mathrm{Y}$ in roots and $\mathrm{Sc}$ in stems.

\section{Content of light rare earth elements}

Two-way ANOVA revealed the highly significant $(\alpha \leq 0.001)$ effect of plant species and organs on the level of all analysed LREEs in all experimental areas (Table S4 in Supplementary data). Diversity in LREEs was observed in all places where plant species were collected (Tables S8-S11 in Supplementary data). The highest content of total LREEs was recorded in leaves of A. millefolium and $P$. rhoeas $(75.0$ and $76.0 \mathrm{mg}$ $\mathrm{kg}^{-1} \mathrm{DW}$, respectively) and $T$. inodorum roots $(55.0 \mathrm{mg} \mathrm{kg}-1$ DW) collected from Area 1. In the case of Area 2, the highest total content of LREEs in was found T. inodorum and A. millefolium leaves (37.3 and $34.2 \mathrm{mg} \mathrm{kg}^{-1} \mathrm{DW}$ ) and P. rhoeas stems $\left(29.6 \mathrm{mg} \mathrm{kg}^{-1} \mathrm{DW}\right)$. Generally, for plants collected from Area 1, the highest content of $\mathrm{Gd}, \mathrm{Ce}, \mathrm{Sm}$, $\mathrm{La}$ and $\mathrm{Eu}$ was observed in T. inodorum roots, while in A. millefolium and $P$. rhoeas leaves the content of $\mathrm{Nd}$ was the highest. In the case of Pr, the highest content of this element was in A. vulgaris leaves and roots (1.55 and $1.43 \mathrm{mg}$ $\mathrm{kg}^{-1} \mathrm{DW}$, respectively) and $T$. inodorum leaves $\left(1.60 \mathrm{mg} \mathrm{kg}^{-1}\right.$ DW), and the highest content of Eu was present in A. vulgaris leaves and $\boldsymbol{T}$. inodorum stems $\left(0.08\right.$ and $0.07 \mathrm{mg} \mathrm{kg}^{-1} \mathrm{DW}$, respectively). The content of Sm was significantly higher in T. inodorum and T. officinale organs than in those of the other plant species.

In the case of plants growing in Area 2, the highest content of Gd, Ce and La was observed in P. rhoeas leaves $(0.32,7.10$ and $1.26 \mathrm{mg} \mathrm{kg}^{-1} \mathrm{DW}$, respectively) and $\mathrm{Sm}$ in $T$. inodorum leaves $\left(0.14 \mathrm{mg} \mathrm{kg}^{-1} \mathrm{DW}\right)$. A. millefolium and T. inodorum leaves contained the highest amount of Nd $(31.2$ and $31.1 \mathrm{mg}$ $\mathrm{kg}^{-1} \mathrm{DW}$ ), while Pr was present in the greatest amount in A. vulgaris leaves and $P$. rhoeas stems (1.35 and $1.20 \mathrm{mg}$ $\left.\mathrm{kg}^{-1} \mathrm{DW}\right)$. A similar and the highest content of Eu was recorded in A. vulgaris and T. inodorum stems and P. rhoeas leaves $\left(0.07,0.08\right.$ and $0.07 \mathrm{mg} \mathrm{kg}^{-1} \mathrm{DW}$, respectively).

For total LREEs the highest content were present in $\boldsymbol{T}$. inodorum roots, $T$. officinale leaves and stems and $P$. rhoeas leaves $\left(61.8,41.4,37.8\right.$ and $37.0 \mathrm{mg} \mathrm{kg}^{-1} \mathrm{DW}$, respectively) 
collected from Area 3, while in plants from Area 4, the highest contents were found in $T$. inodorum, T. officinale and A. millefolium leaves $\left(43.8,33.8\right.$ and $33.6 \mathrm{mg} \mathrm{kg}^{-1} \mathrm{DW}$, respectively). In the case of Area 3, the highest content of Gd and Ce was stated in T. inodorum, $P$. rhoeas and T. officinale roots. These two plant species were additionally found to have accumulated the most La species, while the highest content of Nd was observed in $T$. inodorum roots $\left(54.7 \mathrm{mg} \mathrm{kg}^{-1} \mathrm{DW}\right)$. It is worth noting that a significantly higher content of Sm was stated in A. millefolium stems $\left(0.15 \mathrm{mg} \mathrm{kg}^{-1} \mathrm{DW}\right)$ and $P$. rhoeas leaves $\left(0.10 \mathrm{mg} \mathrm{kg}^{-1} \mathrm{DW}\right)$. Analysis of plants collected from Area 4 revealed a high content of $\mathrm{Ce}$ in the majority of the tested plants, especially in their roots and leaves. A significantly higher content of $\mathrm{Nd}$ was observed in T. inodorum, A. millefolium and T. officinale leaves (38.3, 27.2 and $27.5 \mathrm{mg} \mathrm{kg}^{-1} \mathrm{DW}$, respectively). It is interesting to note that the highest and a similar content of La was stated in A. millefolium and $P$. rhoeas roots $\left(0.61\right.$ and $0.63 \mathrm{mg} \mathrm{kg}^{-1}$ DW, respectively). Additionally, a significantly higher content of $\mathrm{Gd}$ and $\mathrm{Sm}$ (0.21 and $0.11 \mathrm{mg} \mathrm{kg}^{-1} \mathrm{DW}$, respectively) in $P$. rhoeas roots and $A$. millefolium leaves in relation to the rest of the tested plants was observed.

\section{Similarities and differences between plants from particular areas}

The content of the PCA revealed a positive relation between HREEs contents in $T$. inodorum A1 and $P$. rhoeas A1. Another group with a positive relation was as follows: A. vulgaris A2, A. vulgaris A1, A. millefolium A1, A. millefolium A2 and $P$. rhoeas A2. The following species revealed positive relations between them: T. inodorum A2, T. officinale $\mathrm{A} 1$ and $T$. officinale $\mathrm{A} 2$, while showing a negative relation with the rest of the tested species and areas (Fig. 2a). Cluster analysis revealed similarities between such groups as A. vulgaris A2, A. vulgaris A1, T. officinale A1, T. officinale A2, A. millefolium A1 and another group T. inodorum A1 and $P$. rhoeas A1 (Fig. 2b). PCA revealed positive relations between all examined species in Areas 3 and 4, excluding T. officinale A4, T. officinale A3, A millefolium A3, which were characterized by positive relations between them and negative to the remaining species and areas. Additionally a strong positive relationship was noted for A. vulgaris A3 and A. vulgaris A4, as well as for T. inodorum A4 and T. inodorum A3 (Fig. 2c). Based on the obtained cluster analysis the following groups can be identified: A. vulgaris A3, A. vulgaris A4, P. rhoeas A4, T. officinale A4. The next: A. millefolium A4 and T. inodorum A4 and the last $P$. rhoeas A3, A. millefolium A3, T. officinale A3, T. inodorum A3 (Fig. 2d).

For REEs positive relations for Area 1 and Area 2 was observed for all investigated species and areas, excluding T. inodorum A1., which was found in a negative relation to
A. millefolium A1, A. millefolium A2, A. vulgaris A2, $P$. rhoeas A2, A. vulgaris A1, T. officinale A2, T. officinale A1. Strong positive relations were found between the following pairs of species and areas: A. millefolium A1 and A. millefolium A2, $T$. officinale A2 and $T$. officinale A1, $P$. rhoeas A2 and A. vulgaris A1 (Fig. 3a). Based on cluster analysis three groups were created: A. vulgaris A1 with T. officinale A1, then A. vulgaris A2, T. officinale A2, A. millefolium A2, T. inodorum A2, P. rhoeas A2 and the last group A. millefolium A1, P. rhoeas, T. inodorum A1 (Fig. 3b). PCA revealed a negative or a lack of relations between A. millefolium A3 with the other experimental objects. A strong positive relation was noted for A. vulgaris A4, A vulgaris A3 and $P$. rhoeas $\mathrm{A} 4$, as well as between A. millefolium., T. inodorum A3and T. inodorum A4 (Fig. 3c). Cluster analysis allowed three groups with similar responses to be detected: A. vulgaris A3, A. vulgaris A4, T. inodorum A4, the next A. millefolium A3, A. millefolium A4, P. rhoeas A4, T. officinale A4. The last group would include T. officinale A3 and P. rhoeas A3 (Fig. 3d).

The PCA for LREEs revealed negative relations between T. inodorum A1, T. inodorum A2 and P. rhoeas A2. Simultaneously, $P$. rhoeas A2 was found to lack any relation to other species and areas. A strong positive relation was noted between A. millefolium A1 and A. millefolium A2 as well as between $T$. officinale A2 and T. officinale A1 (Fig. 4a). Cluster analysis revealed the following groups: A. vulgaris A1 with T. officinale A, next A. vulgaris A2, T. officinale A2, A. millefolium A2, P. rhoeas A2, T. inodorum A2, and the last, T. inodorum A1, A. millefolium A1, P. rhoeas A1 (Fig. 4b). A negative or a lack of relation was found for $P$. rhoeas A3 with the rest of the experimental objects.

A strong positive relation was noted between $T$. officinale A 3 and T. officinale A4 as well as between A. vulgaris A4 and A. vulgaris A3, and between T. inodorum A3 and T. inodorum A4 (Fig. 4c). Based on cluster analysis the following groups were created: A. vulgaris A3, A. vulgaris A4, T. inodorum A4, then A. millefolium A4, T. officinale A4. The next group A. millefolium A4, T. inodorum A3, P. rhoeas A4, as well as T. officinale A3 and P. rhoeas A3 (Fig. 4d).

The PCA of $A$. vulgaris revealed a negative or lack of relation between leaves A1 and roots A2 with other plant organs and areas. A positive relation was found for stems A1, roots A1 and leaves A2 (Fig. S1a in Supplementary data). A positive relation was also recorded for stems A3, leaves A4, roots A3, leaves A3 and stems A4. Roots A4 did not reveal any relation with the other objects (Fig. S1b). A. millefolium was found to lack or to show a negative relation of roots A1 with other organs and areas, while the rest revealed positive relations between them (Fig. S2a).

PCA revealed positive relations between plant organs in Areas 3 and 4. A strongly positive relation was found for stems A4 and stems A3 as well as for roots A4 and leaves 
a

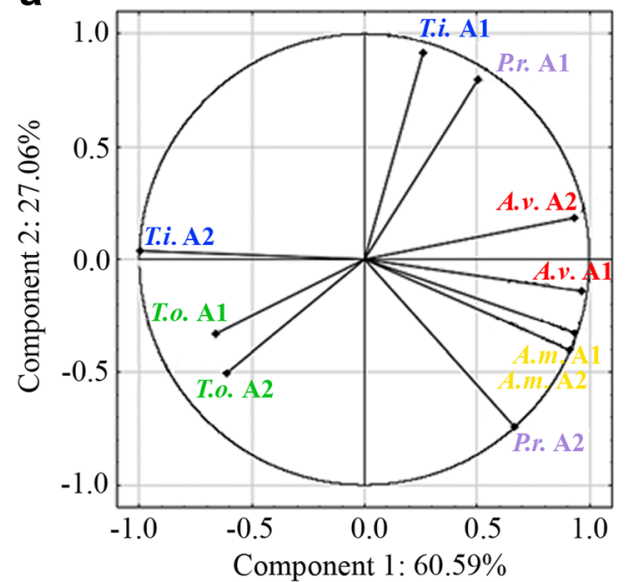

C

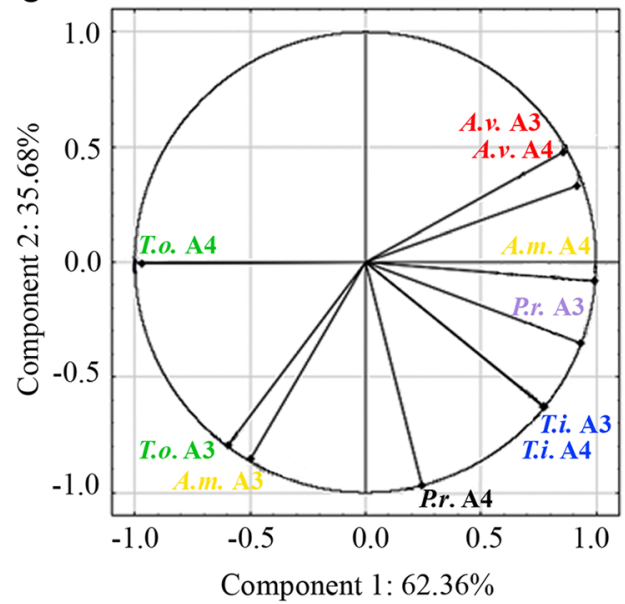

b

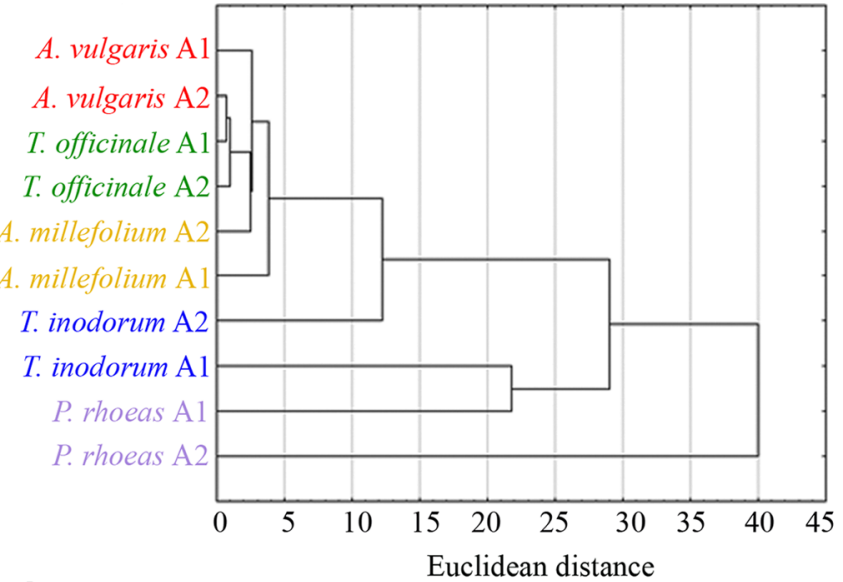

d

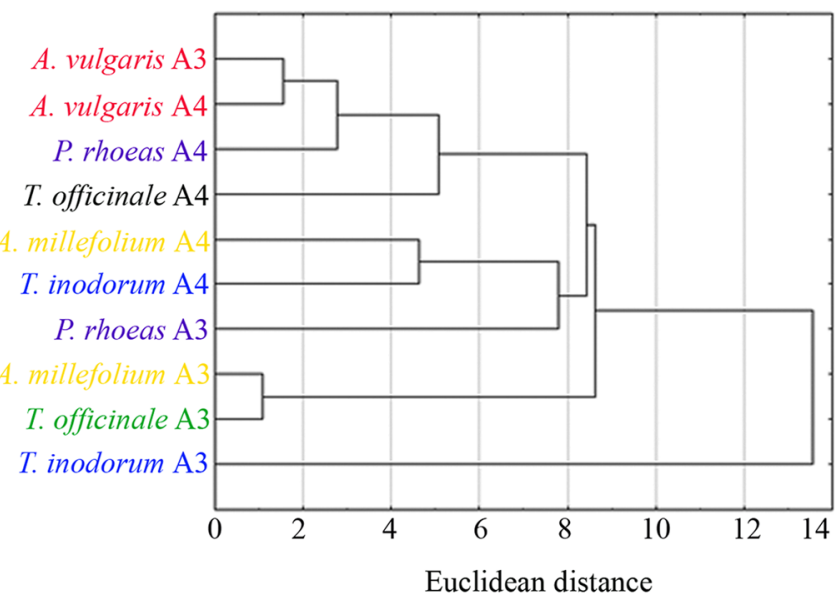

Fig. 2 Principal component analysis (PCA) and cluster analysis of HREEs contents in analysed plant species collected from Area 1 and 2 (a and b) and Area 3 and 4 (c and d)

A4 (Fig. S2b). PCA of REE content in T. odoratum revealed positive relations between all plant organs and areas, excluding roots A2, which was found without relations to stems A2 (Fig. S3a). The rest of the species displayed positive relations between plant organs and areas (Fig. S3b; S4a,b; S5a,b).

\section{Content of REEs, their concentration in soils and road traffic intensity}

The efficiency of REEs (HREEs and LREEs) phytoextraction was diverse, therefore for all tested plants, bioconcentration factor (BCF) and translocation factor (TF) values were calculated to show how effective the uptake and transport of these elements were in the plants (Table 4). BCF values were over 1 for all plants collected from particular experimental areas with the exception of almost all plant species collected from Area 2, 3 and 4 and also: A. vulgaris from Areas 3 and 4 (HREEs, $\mathrm{BCF}=0.87$ and 0.63; LREEs, $\mathrm{BCF}=0.94$ and 0.68 , respectively), A. millefolium from
Area 3 (HREEs, $\mathrm{BCF}=0.98$ ), and also $P$. rhoeas from Area 4 (HREEs, $\mathrm{BCF}=0.47$; LREEs, $\mathrm{BCF}=0.52$ ).

For this reason, generally obtained results showed an accumulation of REEs. What is especially interesting is that $\mathrm{TF}$ values for the majority plant species (especially A. vulgaris, A. millefolium and T. officinale) growing in particular experimental areas was higher than 1, which suggests the effective phytoextraction and transport of REEs from the root system to leaves. Phytoextraction of REEs with a high ability in the majority plants to translocation of these elements was finally compared with plant/soil correlation values. The values presented in Table 4 showed that for T. officinale (LREEs, HREEs and REEs), A. millefolium and T. inodorum (HREEs) values were significantly positive, whereas negative correlations were found for the rest of the species. It is worth underlining that there were clear correlations between total amount of motor vehicles and concentration of REEs, HREEs and LREEs, which pointed to the significant role of traffic intensity in the transport of these elements to the environment. 
a

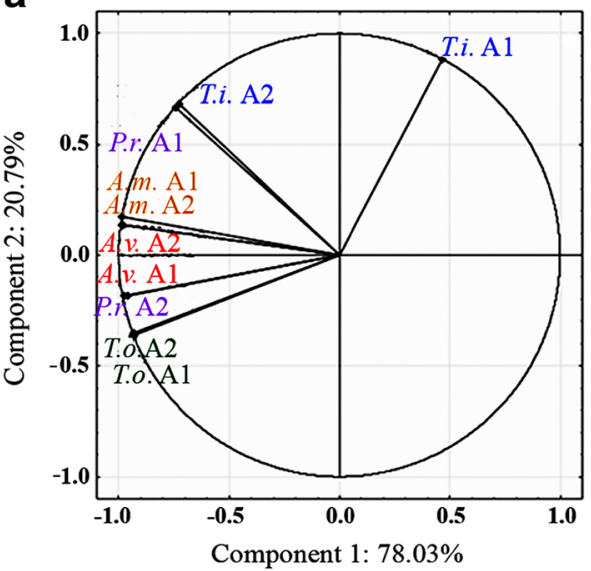

C

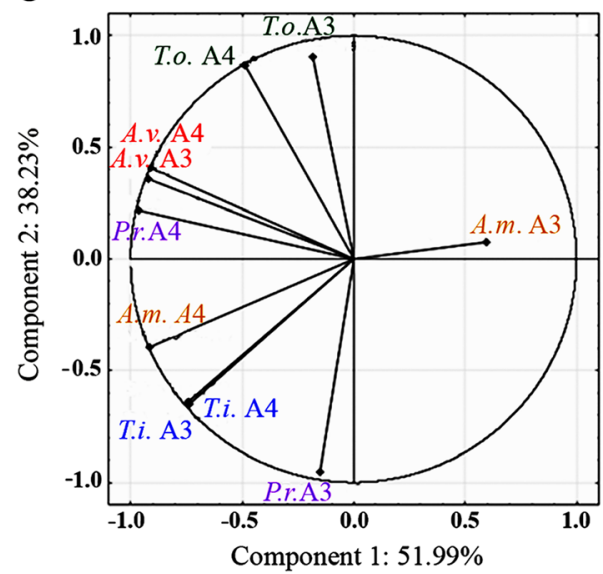

b

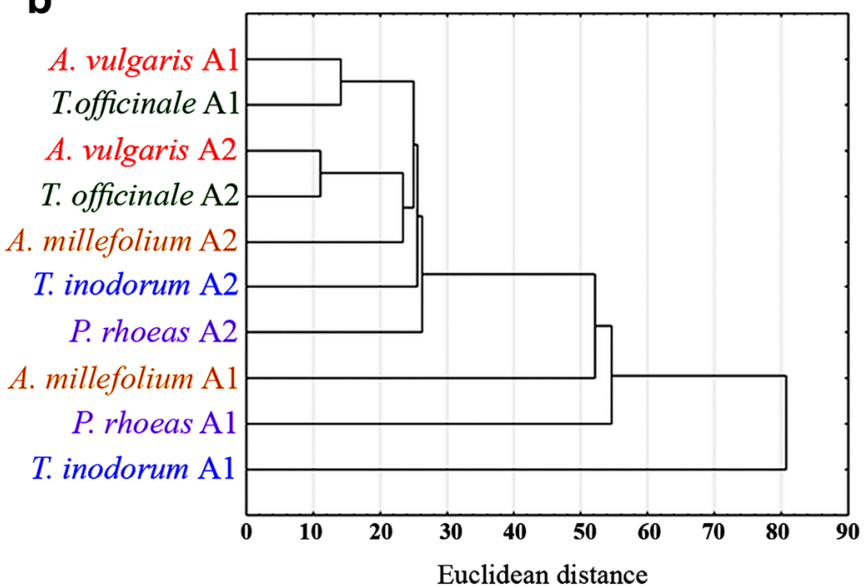

d

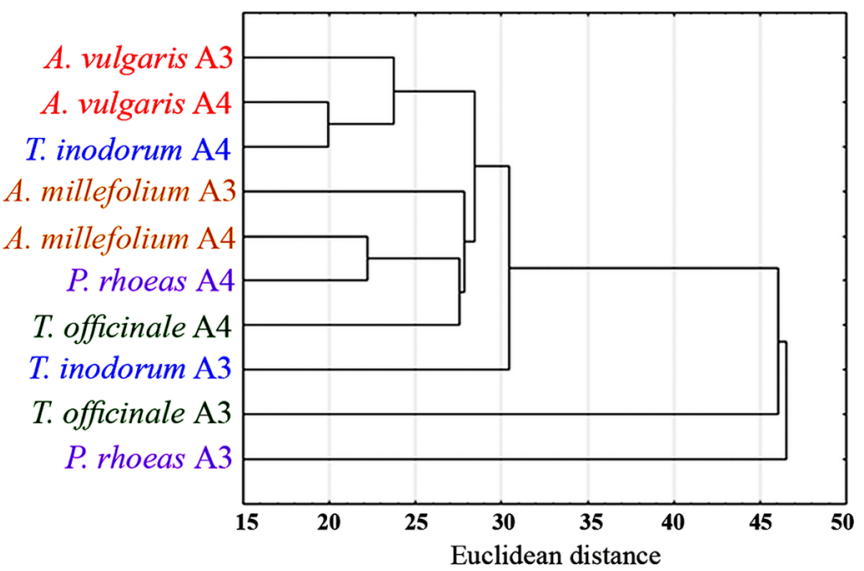

Fig. 3 Principal component analysis (PCA) and cluster analysis of REEs contents in analysed plant species collected from Area 1 and 2 (a and b) and Area 3 and 4 (c and d)

\section{Comparison of the two years of herbaceous plant studies}

Analysis of plant material collected in 2015 and 2016 revealed that the above mentioned relationships between plants as regards their ability for total REE phytoextraction and translocation to particular organs (root, stem, leaf) were the same. Moreover, the same relationships between plants collected from particular experimental areas were also identical. However, the efficiency of all tested plant species to phytoextraction of LREEs and HREEs in both years was markedly different. Generally, with three insignificant exceptions, the efficiency of LREEs, HREEs and REEs was higher in 2016 than 2015. The content of total REEs in roots, stems and leaves for all tested plant species was 7-37, 8-42 and 10-44\%, respectively; higher in 2016 than 2015. The presentation of the 2015 results only was not accidental as regards to much data of show in regular paper but mainly to confirm the similarities of the relations between plants in particular years.

\section{Discussion}

There are abundant data in the literature that describe the phytoextraction of heavy metals in plants growing in the vicinity of roads (Djingova et al. 2003; Vince et al. 2014; Adelasoye and Alamu 2016), especially as regards the implications for human health (Zhang et al. 2012). Unfortunately, in the case of REEs these data are rather modest, most likely as a result of the analytical difficulties associated with analysis of this element group (Borovička et al. 2011). Although there are currently appropriate tools for REEs analysis our knowledge of the potential of the herbaceous plant species tested in this paper for the phytoextraction of these and other elements is still limited (Keane et al. 2001; Figueiredo et al. 2009; Alvarenga et al. 2015). Djingova et al. (2003) have analysed $\mathrm{Ce}, \mathrm{La}$ and $\mathrm{Nb}$ content in selected plant species and mushrooms collected along streets and highways in Germany. T. officinale tested in our paper was found to be one of the most effective in phytoextraction in soil polluted with the analysed elements and heavy metals (Petrova et al. 2013), 

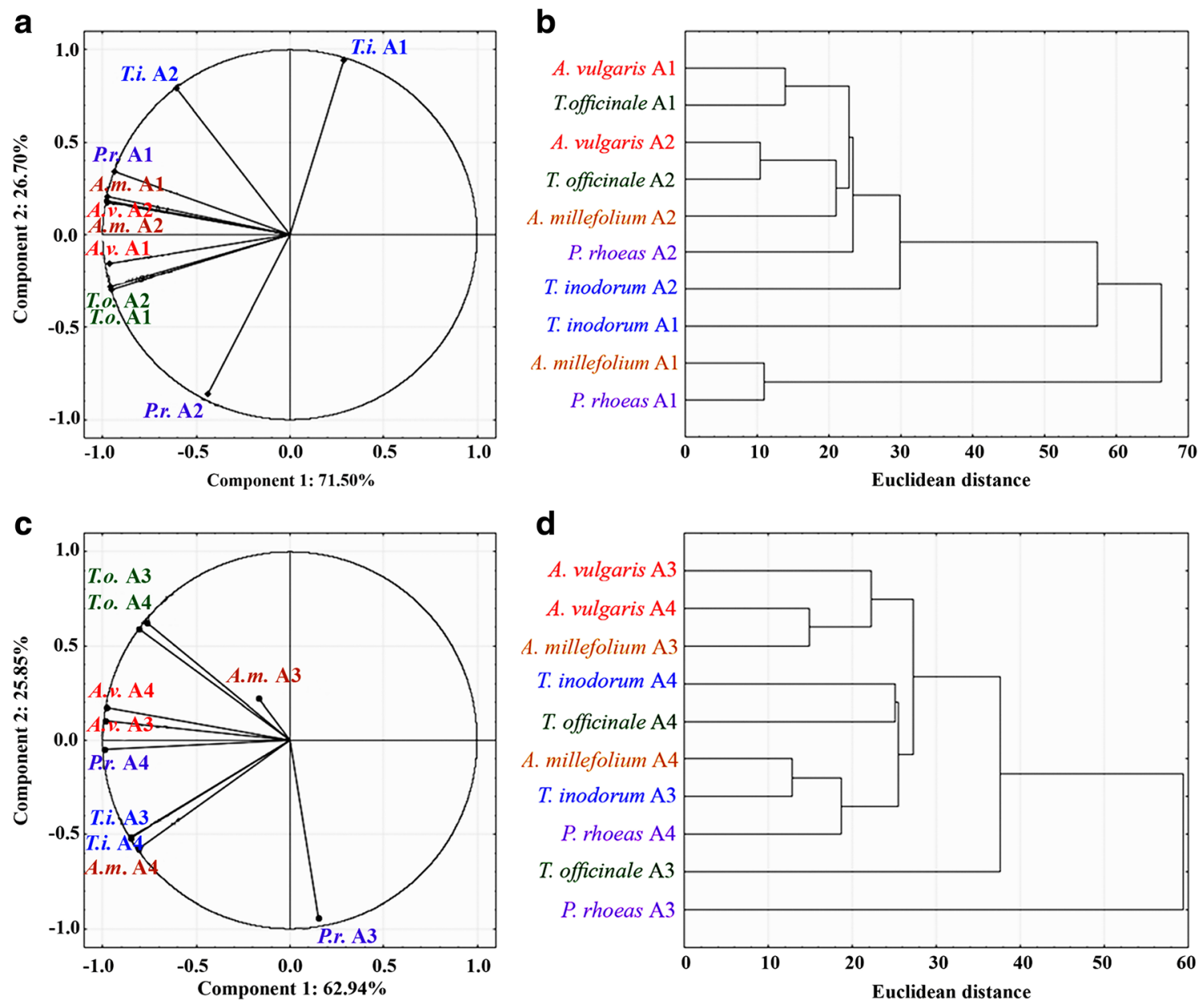

Fig. 4 Principal component analysis (PCA) and cluster analysis of LREEs contents in analysed plant species collected from Area 1 and 2 (a and b) and Area 3 and 4 (c and d)

particularly in its stems and roots (Bini et al. 2012) but also in leaves (Keane et al. 2001). The higher ability of this plant species when compare to the other plants e.g. A. millefolium was presented by Gonçalves et al. (2013) as regards selected REEs phytoextraction or by Grzegorczyk et al. (2013) for potassium $(\mathrm{K})$, calcium $(\mathrm{Ca})$ and magnesium $(\mathrm{Mg})$ accumulation. The observed differences, that pointed to a higher or lower content of particular elements in $T$. officinale and A. millefolium (Radulescu et al. 2013), cannot indicate the real potential of particular plant species for REEs phytoextraction in their organs. This confirms the results of macroelement content as presented by Ștef et al. (2010) in relation to the data of Grzegorczyk et al. (2013). The same situation, relating to a diverse content of $\mathrm{As}, \mathrm{Cd}, \mathrm{Cu}, \mathrm{Pb}$ and $\mathrm{Zn}$ in particular T. officinale organs, was shown by Bech et al. (2016). Additionally, authors have calculated TF values for the above mentioned metals/metalloids as being generally below 2.1, which reflects the results for total REEs as presented in this paper. It is worth pointing out that the content of HREEs was generally similar or higher in roots than in leaves, whereas in the case of LREEs, the content in leaves was higher than in roots, which confirm the results obtained by Durães et al. (2014). This would suggest that the tested plant species have a limited ability to translocate HREEs from their root system to the aerial parts. This fact is verified by the majority of observations presented using TF values in Table 4.

When we compare the following ratios: stems/roots, leaves/roots and leaves/stems according to data presented by Durães et al. (2014), we did not generally observe any similarities in the differences between these ratios and higher values of ratios, especially for $\mathrm{Nd}, \mathrm{Gd}$ and Er. Additionally, when comparing $\mathrm{BCF}$ calculated for ratios: plant/rhizosphere or organ/rhizosphere, only some relationships were observed. Durães et al. (2014) pointed to differences in the BCF values of particular HREEs and similar values of BCF for LREEs. In our studies only some observations for selected REEs were compared. The reason for the presented differences was probably connected to the higher efficiency of $\mathrm{Nd}$, Er or $\mathrm{Ce}$ phytoextraction in the tested plants as well as differences in REEs concentration in soils from particular experimental areas. Environmental factors significantly influence element phytoextraction, as confirmed in numerous papers (Zhuang 
Table 4 Characteristics of bioaccumulaton (BAF) and translocation (TF) factors with characteristics of two correlations: amount of motor vehicles - concentration of REEs in soil and REEs concentration in soil to their content in plant, calculated based on all observations from all experimental areas (A1-A4)

\begin{tabular}{|c|c|c|c|c|c|c|c|c|c|c|c|c|c|}
\hline \multirow[t]{2}{*}{ Plant species } & \multirow{2}{*}{$\begin{array}{l}\text { Factor/ } \\
\text { correlation }\end{array}$} & \multicolumn{4}{|c|}{ HREEs } & \multicolumn{4}{|c|}{ LREEs } & \multicolumn{4}{|l|}{ REEs } \\
\hline & & $\mathrm{A} 1$ & $\mathrm{~A} 2$ & $\mathrm{~A} 3$ & A4 & $\mathrm{A} 1$ & $\mathrm{~A} 2$ & A3 & A4 & A1 & $\mathrm{A} 2$ & A3 & A4 \\
\hline \multirow[t]{3}{*}{ A. vulgaris } & $\mathrm{BCF}$ & 1.90 & 1.01 & 0.87 & 0.63 & 2.12 & 1.19 & 0.94 & 0.68 & 1.00 & 0.55 & 0.45 & 0.33 \\
\hline & $\mathrm{TF}$ & 1.2 & 1.0 & 1.4 & 1.1 & 2.5 & 2.3 & 3.5 & 2.9 & 2.3 & 2.2 & 3.2 & 2.7 \\
\hline & Plant - soil & \multicolumn{4}{|c|}{$r=-0.245, p=0.755$} & \multicolumn{4}{|c|}{$r=-0.408, p=0.539$} & \multicolumn{4}{|c|}{$r=-0.415, p=0.585$} \\
\hline \multirow[t]{3}{*}{ A. millefolium } & $\mathrm{BCF}$ & 2.39 & 1.40 & 0.98 & 1.02 & 2.66 & 1.66 & 1.05 & 1.11 & 1.26 & 0.76 & 0.51 & 0.53 \\
\hline & $\mathrm{TF}$ & 1.6 & 1.8 & 0.5 & 0.8 & 4.1 & 4.5 & 1.0 & 1.3 & 3.7 & 4.1 & 1.0 & 1.2 \\
\hline & Plant - soil & \multicolumn{4}{|c|}{$r=0.849, p=0.151$} & \multicolumn{4}{|c|}{$r=-0.390, p=0.610$} & \multicolumn{4}{|c|}{$r=-0.270, p=0.730$} \\
\hline \multirow[t]{3}{*}{ T. inodorum } & $\mathrm{BCF}$ & 2.32 & 1.72 & 1.15 & 1.21 & 2.49 & 2.03 & 1.24 & 1.32 & 1.19 & 0.93 & 0.60 & 0.63 \\
\hline & $\mathrm{TF}$ & 0.1 & 0.3 & 0.3 & 0.3 & 0.8 & 1.4 & 1.3 & 1.3 & 0.6 & 1.3 & 1.0 & 1.0 \\
\hline & Plant - soil & \multicolumn{4}{|c|}{$r=0.275, p=0.725$} & \multicolumn{4}{|c|}{$r=-0.612, p=0.388$} & \multicolumn{4}{|c|}{$r=-0.525, p=0.475$} \\
\hline \multirow[t]{3}{*}{ P. rhoeas } & $\mathrm{BCF}$ & 3.40 & 2.40 & 1.17 & 0.47 & 3.79 & 2.83 & 1.25 & 0.52 & 1.79 & 1.30 & 0.60 & 0.25 \\
\hline & $\mathrm{TF}$ & 0.3 & 7.8 & 0.6 & 0.3 & 0.8 & 1.4 & 0.5 & 2.2 & 1.6 & 2.9 & 0.5 & 2.0 \\
\hline & Plant - soil & \multicolumn{4}{|c|}{$r=-0.889, p=0.111$} & \multicolumn{4}{|c|}{$r=-0.056, p=0.944$} & \multicolumn{4}{|c|}{$r=-0.348, p=0.652$} \\
\hline \multirow[t]{3}{*}{ T. officinale } & $\mathrm{BCF}$ & 2.06 & 1.07 & 1.63 & 1.26 & 2.30 & 1.26 & 1.75 & 1.38 & 1.09 & 0.58 & 0.84 & 0.66 \\
\hline & $\mathrm{TF}$ & 1.0 & 1.0 & 0.5 & 1.4 & 4.2 & 4.3 & 1.3 & 2.2 & 3.9 & 4.1 & 1.2 & 2.2 \\
\hline & Plant - soil & \multicolumn{4}{|c|}{$r=0.898, p=0.102$} & \multicolumn{4}{|c|}{$r=0.753, p=0.247$} & \multicolumn{4}{|c|}{$r=0.774, p=0.226$} \\
\hline \multicolumn{2}{|c|}{ Motor vehicles amount - soil } & \multicolumn{4}{|c|}{$r=0.992, p=0.008$} & \multicolumn{4}{|c|}{$r=0.996, p=0.004$} & \multicolumn{4}{|c|}{$r=0.995, p=0.005$} \\
\hline
\end{tabular}

et al. 2007; Mleczek et al. 2009; Laghlimi et al. 2015). Cao et al. (2001) have shown that changes of $\mathrm{pH}$ and redox potential (Eh), affected REEs phytoextraction, especially in relation to $\mathrm{Ce}, \mathrm{Gd}$, La and Y. In our study, some relations confirmed this result but for selected elements and tested areas only, which suggests that phytoextraction of REEs is dependent on many other environmental factors.

Ghimire (2015) in her Master's Thesis described a correlation between the number of vehicles and $\mathrm{Cu}, \mathrm{Cr}, \mathrm{Fe}, \mathrm{Ni}, \mathrm{Pb}$ and $\mathrm{Sn}$ concentration in soil to show generally lower $\mathrm{R}^{2}$ values than in our paper. This fact might suggest that one of the sources of REEs is traffic. It is well known that REEs are present not only in electric and hybrid vehicles (eg. La or Dy in NIMH batteries) but also in traditional vehicles (catalytic converters made of $\mathrm{Ce}, \mathrm{Zr}$ and $\mathrm{La}$ or UV cut glass made of Ce) (Lyubomirova et al. 2011). An increase in the amount of REEs used in the production of new vehicles is the reason for the rise of these elements in soil and finally in plants growing near roads. For this reason it is necessary to carefully monitor these elements, perhaps in accordance with the proposals of Angelone et al. (2002), who suggested that the use of platinum $(\mathrm{Pt})$ in catalytic converters be subject to close control.

As data in the literature is significantly limited, to discuss the obtained results we compared the observed relationships describing heavy metal contents presented in other papers. Degórski and Zawiska (2015) have clearly shown that a relationship exists between traffic intensity and $\mathrm{Ni}, \mathrm{Pb}, \mathrm{Cu}, \mathrm{Zn}$,
$\mathrm{Cd}$, and $\mathrm{Cr}$ concentration in soils, providing confirmation of the major role of this source of heavy metals in the environment. The same observations were documented by Aslam et al. (2013), who found a relationship between the amount of vehicles and $\mathrm{Cd}, \mathrm{Pb}, \mathrm{Cu}, \mathrm{Ni}, \mathrm{Fe}, \mathrm{Mn}$ and $\mathrm{Zn}$ concentration in the soil of Dubai (United Arab Emirates). The authors stated that vehicles are the main source of these elements in soil, which in many cases did not correspond to data presented by Oludare et al. (2013) and especially data described by Akpan and William (2014), who have shown Pearson's correlation in both positive and negative values for these and many other elements. The same observations confirmed the results obtained for REEs (significantly high values of correlation coefficient for amount of motor vehicles and REEs concentration in soil) in this paper, as do those of Czaja et al. (2014) for heavy metals. Our results indicated that the principal source of REEs (both LREEs and HREEs) in soil in the vicinity of roads is motor transport.

The analysis of two years of studies and comparison of the obtained results showed that plants growing in the same experimental areas react in the same way to environmental factors (rain, soil properties or traffic intensity). This was confirmed by the fact that the same relationships were observed between the efficiency of REE phytoextraction in the organs of tested plant species in both 2015 and 2016. Simultaneously, higher phytoextraction of REEs in 2016 was most likely caused by differing weather conditions - drought in 2015, higher temperature, lower precipitation and the standard 
weather conditions in summer 2016 with more rainy days (Table S2). The obtained results clearly illustrate that the various abilities of the tested plant species for REEs phytoextraction are characteristic of them and independent of the year of growth.

\section{Conclusions}

The problem of toxic elements is especially serious when considering the amount of this environmental pollution and that it results from diverse human activities. New technologies offer numerous promising materials but their production is often related to the emission of various elements directly to the environment. In many cases, REEs remain after the production of new materials and their amount in the environment has markedly increased within the last 15 years. For this reason, biological methods such as phytoremediation should be used to decrease REEs transport within the environment and from entering the food chain. The results presented in this paper have shown the potential of A. vulgaris, P. rhoeas, T. inodorum and T. officinale to decontaminate soil in which these elements occur in spite of their clear exclusion being probably effect of REEs immobilization (to high $\mathrm{pH}$ value of soil). On the other hand, easy transport of REEs from the root system to leaves is one of the most important criteria in effective phytoextraction strategy and it has been shown that the above mentioned plant species are able to effectively store REEs in their aboveground plant parts (easy removal of plant parts from environment).

Acknowledgements This study is a part of a $\mathrm{PhD}$ thesis by Patrycja Mikołajczak and was supported by the Polish Ministry of Science and Higher Education of Poland through statutory funds of the Department of Ecology and Environmental Protection, Poznan University of Life Sciences.

Open Access This article is distributed under the terms of the Creative Commons Attribution 4.0 International License (http:// creativecommons.org/licenses/by/4.0/), which permits unrestricted use, distribution, and reproduction in any medium, provided you give appropriate credit to the original author(s) and the source, provide a link to the Creative Commons license, and indicate if changes were made.

\section{References}

Adelasoye KA, Alamu LO (2016) Accumulation of heavy metal pollutants in soil and vegetation and their effects on soil microbial population on roadsides in Ogbomoso, Nigeria. J Environ Sci Water Res $5: 1-7$

Akpan IO, William ES (2014) Assessment of elemental concentrations of roadside soils in relation to traffic density in Calabar, Nigeria. Int $\mathbf{J}$ Sci Technol Res 3:65-70

Ali H, Khan E, Anwar SM (2013) Phytoremediation of heavy metals concepts and applications. Chemosphere 91:869-881. doi:10.1016/ j.chemosphere.2013.01.075
Alvarenga ICA, Boldrin PF, Pacheco FV, Silva ST, Bertolucci SKV, Pinto JEBP (2015) Effects on growth, essential oil content and composition of the volatile fraction of Achillea millefolium L. cultivated in hydroponic systems deficient in macro- and microelements. Sci Hortic-Amsterdam 197:329-338. doi:10.1016/j.scienta.2015.09. 046

Angelone M, Armiento G, Cinti D, Somma R, Trocciola A (2002) Platinum and heavy metal concentration levels in urban soils of Naples (Italy). Fresenius Environ Bull 11:432-436

Aslam J, Khan SA, Khan SH (2013) Heavy metals contamination in roadside soil near different traffic signals in Dubai, United Arab Emirates. Journal of Saudi Chemical Society 17:315-319. doi:10. 1016/j.jscs.2011.04.015

Bech J, Roca N, Tume P, Ramos-Miras J, Gil C, Boluda R (2016) Screening for new accumulator plants in potential hazards elements polluted soil surrounding Peruvian mine tailings. Catena 136:66-73. doi:10.1016/j.catena.2015.07.009

Bentlin FRS, Pozebon D (2010) Direct determination of lanthanides in environmental samples using ultrasonic nebulization and ICP OES. J Braz Chem Soc 21:627-634. doi:10.1590/S010350532010000400007

Bini C, Wahsha M, Fontana S, Maleci L (2012) Effects of heavy metals on morphological characteristics of Taraxacum officinale web growing on mine soils in NE Italy. J Geochem Explor 123:101-108. doi: 10.1016/j.gexplo.2012.07.009

Bluemel B, Leijd M, Dunn C, Hart CJR, Saxon M, Sadeghi M (2013) Biogeochemical expression of rare earth element and zirconium mineralization at Norra Kärr, southern Sweden. J Geochem Explor 133:15-24. doi:10.1016/j.gexplo.2012.12.005

Borovička J, Kubrová J, Rohovec J, Řanda Z, Dunn CE (2011) Uranium, thorium and rare earth elements in macrofungi: what are the genuine concentrations? Biometals 24:837-845. doi:10.1007/s10534-0119435-4

Byrne RH, Liu X, Schijf J (1996) The influence of phosphate precipitation of rare earth distributions in natural waters. Geochim Cosmochim AC 60:3341-3346. doi:10.1016/0016-7037(96) 00197-4

Cao XD, Chen Y, Gu ZM, Wang XR (2000) Determination of trace rare earth elements in plant and soil samples by inductively coupled plasma-mass spectrometry. Int J Environ Anal Chem 76:295-309. doi:10.1080/03067310008034137

Cao XD, Chen Y, Gu ZM, Wang X, Deng X (2001) Effects of redox potential and $\mathrm{pH}$ value on the release of rare earth elements from soil. Chemosphere 44:655-661. doi:10.1016/S0045-6535(00) 00492-6

Carrero JA, Arrizabalaga I, Bustamante J, Goienaga N, Arana G, Madariaga JM (2013) Diagnosing the traffic impact on road sides oils through a multianalytical data analysis of the concentration profiles of traffic-related elements. Sci Total Environ 458-460:427-434. doi:10.1016/j.scitotenv.2013.04.047

Chiarenzelli J, Aspler L, Dunn C, Cousens B, Ozarko D, Powis K (2001) Multi-element and rare earth element composition of lichens, mosses, and vascular plants from the central Barrenlands, Nunavut, Canada. ApplGeochem 16:245-270. doi:10.1016/S08832927(00)00027-5

Czaja M, Kołton A, Baran A, Muras P (2014) Influence of urban transport on heavy metals accumulation in the leaves of lime trees in Cracow. Logistyka - nauka 4:4193-4197

Degórski M, Zawiska I (2015) The influence of car traffic on the sanitary state of the soil. EUROPA XXI 28:139-150

Ding S, Liang T, Zhang C, Yan J, Zhang Z, Sun Q (2005) Role of ligands in accumulation and fractionation of rare earth elements in plants. Examples of phosphate and citrate. Biol Trace Elem Res 107:73-86. doi:10.1385/BTER:107:1:073

Djingova R, Kovacheva P, Wagner G, Markert B (2003) Distribution of platinum group elements and other traffic related elements among 
different plants along some highways in Germany. Sci Total Environ 308:235-246. doi:10.1016/S0048-9697(02)00677-0

Durães N, da Silva EF, Bobos I, Ávila P (2014) Rare Earth Elements fractionation in native vegetation from the Moncorvo iron Mines, NE Portugal. Procedia Earth and Planetary Science 10:376-382. doi:10.1016/j.proeps.2014.08.064

EPA 600/R-12/572 (2012) Rare Earth Elements: A Review of Production, Processing, Recycling, and Associated Environmental Issues.

Figueiredo, AMG, Camargo SP, Sígolo JB (2009) Determination of REE in urban park soils from Sao Paulo City for finger print of traffic emission contamination. International Nuclear Atlantic Conference INAC 2009 Rio de Janeiro, RJ, Brazil, September 27-October 2.

Gambogi J (2011) Rare earths. U.S. Geological Survey Minerals Yearbook - 2011. 60-60.12.

Ghimire CK (2015) Assessment of Metals and Organic Contaminants in Roadside Soils and Plants in Greater Victoria, British Columbia, Canada. Victoria, British Columbia, Canada. Master Thesis.

Gonçalves RDMR, Francisconi LS, da Silva PSC (2013) Rare earth elements determination in medicinal plants by neutron activation analysis. International Nuclear Atlantic Conference, Recife, PE, Brazil.

Grzegorczyk S, Alberski J, Olszewska M (2013) Accumulation of potassium, calcium and magnesium by selected species of grassland legumes and herbs. J Elem 18:69-78. doi: 10.5601/jelem.2013.18.1.05

ISO 11271 (2002) Soil quality. Determination of redox potential. Field method.

Keane B, Collier MH, Shann JR, Rogstad SH (2001) Metal content of dandelion (Taraxacum officinale) leaves in relation to soil contamination and airborne particulate matter. Sci Total Environ 281:6378. doi:10.1016/S0048-9697(01)00836-1

Klinger JM (2015) A historical geography of rare earth elements: from discovery to the atomic age. The Extractive Industries and Society 2: 572-580. doi:10.1016/j.exis.2015.05.006

Laghlimi M, Baghdad B, El Hadi H, Bouabdli A (2015) Phytoremediation mechanisms of heavy metal contaminated soils: a review. Open Journal of Ecology 5:375-388. doi:10.4236/oje. 2015.58031

Laveuf C, Cornu S (2009) A review on the potentiality of rare earth elements to trace pedogenetic processes. Geoderma 154:1-12. doi: 10.1016/j.geoderma.2009.10.002

Lyubomirova V, Djingova R, van Elteren JT (2011) Fractionation of traffic-emitted Ce, la and $\mathrm{Zr}$ in road dusts. J Environ Monit 13: 1823-1830. doi:10.1039/c1em10187k

Mleczek M, Magdziak Z, Rissmann I, Golinski P (2009) Effect of different soil conditions on selected heavy metals accumulation by Salix viminalis tissues. J Environ Sci Health A 44:1613-1620. doi:10. 1080/10934520903263645

Mleczek M, Niedzielski P, Kalač P, Siwulski M, Rzymski P, Gąsecka M (2016a) Levels of platinum group elements and rare earth elements in wild mushroom species growing near a busy trunk road. Food Addit Contam A 33:86-94. doi:10.1039/c1em10187k

Mleczek M, Rutkowski P, Niedzielski P, Goliński P, Gąsecka M, Kozubik T, Dąbrowski J, Budzyńska S, Pakuła J (2016b) The role of selected tree species in industrial sewage sludge/flotation tailing management. Int J Phytoremediat 18:1086-1095. doi:10.1080/15226514. 2016.1183579
Nakamaru Y, Tagami K, Uchida S (2006) Effect of nutrient uptake by plant roots on the fate of REEs in soil. JAlloy Compd 408-412:413416. doi:10.1016/j.jallcom.2004.12.102

Oludare AH, Oluwafunmilayo OO, Ovebanji FF (2013) Assessment of traffic related heavy metals pollution of roadside soils in emerging urban Ccntres in Ijebu-north area of Ogun State, Nigeria. J Appl Sci Environ. Manag 17:509-514. doi:10.4314/jasem.v17i4.8

Petrova S, Yurukova L, Velcheva I (2013) Taraxacum officinale As a biomonitor of metals and toxic elements (Plovdiv, Bulgaria). Bulg J Agric Sci 19:241-247

PN-ISO 10390 (1997) Jakość gleby. Oznaczanie pH. (Soil quality. Determination of $\mathrm{pH}$.) [in Polish]

PN-ISO 11465 (1999) Jakość gleby. Oznaczanie zawartości suchej masy gleby i wody w glebie w przeliczeniu na suchą masę gleby. Metoda wagowa. (Soil quality. Determination of dry matter and water content on a mass basis. Gravimetric method.) [in Polish]

PN-ISO 1265+AC1 (1997) Jakość gleby. Oznaczanie przewodności elektrolitycznej. (Soil quality. Determination of electrolytic conduction.) [in Polish]

Radulescu C, Stihi C, Poposcu IV, Ionita I, Dulama ID, Chilian A, Bancuta OR, Chelarescu ED, Let D (2013) Assessment of heavy metals level in some perennial medicinal plants by flame atomic absorption spectrometry. Rom Rep Phys 65:246-260

Saatz J, Vetterlein D, Mattusch J, Otto M, Daus B (2015) The influence of gadolinium and yttrium on biomass production and nutrient balance of maize plants. Environ Pollut 204:32-38. doi:10.1016/j.envpol. 2015.03.052

Ștef DS, Gergen I, Ștef L, Hărmănescu M, Pop C, Drugă M, Bujancă G, Popa M (2010) Determination of the macro elements content of some medicinal herbs. Animal Science and Biotechnologies 43: $122-126$

Tyler G (2004) Rare earth elements in soil and plant systems - a review. Plant Soil 267:191-206. doi:10.1007/s11104-005-4888-2

Vince T, Szabó G, Csoma Z, Sándor G, Szabó S (2014) The spatial distribution pattern of heavy metal concentrations in urban soils - a study of anthropogenic effects in Berehove, Ukraine. Cent Eur J Geosci 6:330-343. doi:10.2478/s13533-012-0179-7

Wiche O, Heilmeier H (2016) Germanium (Ge) and rare earth element (REE) accumulation in selected energy crops cultivated on two different soils. Miner Eng 92:208-215. doi:10.1016/j.mineng.2016.03.023

Yu Z, Zhou Q (2009) Growth responses and cadmium accumulation of Mirabilis jalapa L. under interaction between cadmium and phosphorus. J Hazard Mater 167:38-43. doi:10.1016/j.jhazmat.2008.12.082

Zhang SR, Li L, Xu XX, Li T, Gong GS, Deng OP, Pu YL (2015) Lanthanum tolerance and accumulation characteristics of two eucalyptus species. Ecol Eng 77:114-118. doi:10.1016/j.ecoleng.2015. 01.018

Zhang C, Li Q, Zhang M, Zhang N, Li M (2013) Effects of rare earth elements on growth and metabolism of medicinal plants. Acta Pharm Sinica B 3:20-24. doi:10.1016/j.apsb.2012.12.005

Zhang F, Yan X, Zeng C, Zhang M, Shrestha S, Devkota LP, Yao T (2012) Influence of traffic activity on heavy metal concentrations of roadside farmland soil in mountainous areas. Int $\mathrm{J}$ Environ Res Public Health 9:1715-1731. doi:10.3390/ijerph9051715

Zhuang P, Yang QW, Wang HB, Shu WS (2007) Phytoextraction of heavy metals by eight plant species in the field. Water Air Soil Pollut 184:235-242. doi:10.1007/s11270-007-9412-2 